\title{
Dimension optimization of multi-band microstrip antennas using deep learning methods
}

\section{Çoklu banda sahip mikroşerit antenlerde boyut optimizasyonunun derin öğrenme yöntemleri ile gerçekleştirilmesi}

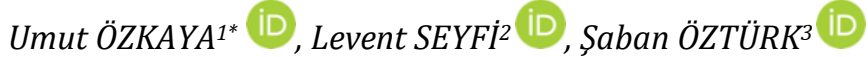 \\ 1,2Department of Electric-Electronic-Engineering, Engineering and Natural Science Faculty, Konya Technical Univ., Konya, Turkey. \\ uozkaya@ktun.edu.tr, lseyfi@ktun.edu.tr \\ 3Department of Electric and Electronic Engineering, Technology Faculty, Amasya University, Amasya, Turkey. \\ saban.ozturk@amasya.edu.tr
}

\begin{abstract}
The electromagnetic frequency spectrum is divided into different subfrequency bands. These sub-frequency bands are allocated for different applications. In these days, devices operating in multiple sub-frequency bands provide significant advantages. Devices require antenna structures to operate in multiple frequency bands. Microstrip antennas have become prominent antenna structures with their small size, portable structures and easy integration into other systems. In this study, microstrip antenna structure which can work in multi frequency bands is designed. At the same time, it was used with deep learning methods in optimization of antenna sizes to ensure the optimization of the designed antenna in a shorter time. The operating frequencies of designed antenna structure work in the $C$ and $X$ band as seen in the obtained results. According to IEEE standards, $C$ band is determined between $4 \mathrm{GHz}$ and $8 \mathrm{GHz}$; X band determined as in $8 \mathrm{GHz}$ and $12 \mathrm{GHz}$ frequency range. In the proposed antenna structure, the ability to operate in multi-band structures was achieved by means of a $C$-shaped antenna array. In the deep learning methods that will be used in the optimization process, five different Long Short Term Memory (LSTM) models are used. The most important advantage of deep learning methods is that it can achieve satisfactory results by identifying the necessary features for solving difficult and time consuming problems with its own learning ability. In this context, 52 pieces of antenna data were produced. 40 pieces of data were used in the training process and 12 pieces of data were used in the test stage. The lowest root mean square error (RMSE) performance obtained in the test data was determined as LSTM-1 + Dropout layer -1 + LSTM - 2 + Dropout layer -2 and 1.0161 error value. The obtained results by proposed method were evaluated in High Frequency Simulation Software (HFSS) program. In experimental results, it was observed that the results produced by the deep learning model and the test data were very close to each other.
\end{abstract}

Keywords: Microstrip antenna, Deep learning, Long short-term memory, Optimization, C-Shaped microstrip antenna array.

\section{Introduction}

At the beginning of 1950 s, it was proved that data can be transmitted with electromagnetic waves as wirelessly [1]. Deschamps first developed a planar microstrip antenna with a transmission line. In the 1970s, microstrip antennas began to be used with dielectric materials [2].

\section{Öz}

Elektromanyetik frekans spektrumu farkl alt frekans bantlara ayrılmıştır. Bu alt frekans bantları, farklı uygulamalar için tahsis edilmiştir. Günümüzde çoklu alt frekans bantlarında çalışan cihazlar önemli avantajlar sağlamaktadır. Cihazlar, çoklu frekans bantlarında çalışması için anten yapılarına ihtiyaç duyar. Mikroşerit antenler, boyutlarının küçük olması, tașınabilir yapıları ve diğer sistemlere kolay bir şekilde entegre olması ile öne çıkan anten yapıları olmuştur. Bu çalıșmada, çoklu frekans bantlarında çalıșabilen mikroșerit anten yapısı tasarlanmıștır. Aynı zamanda, tasarlanan antenin optimizasyonunu daha kısa sürede sağlamak için anten boyutlarının optimizasyonunda derin öğrenme yöntemleri ile kullanılmıștır. Tasarlanan anten yapısının çalış̧a frekansları elde edilen sonuçlarda görüldüğü üzere $C$ ve $X$ bandında çalıșmaktadır. IEEE Standartlarına göre $C$ bandl $4 \mathrm{GHz}$ ile $8 \mathrm{GHz}$ arasinda ve $X$ bandl $8 \mathrm{GHz}$ ile $12 \mathrm{GHz}$ frekans aralığı olarak belirlenmiștir. Önerilen anten yapısında, çoklu bant yapılarında çalıșma özelliği, $C$-șekilli anten dizisi vasıtasılyla elde edilmiștir. Optimizasyon ișleminde kullanılacak olan derin ögrenme yöntemlerinde ise beș farklı Uzun Kısa Süreli Bellek (UKSB) modeli kullanılmıștır. Derin ögrenme yöntemlerinin en önemli avantajı, zorlu ve zaman alıcl problemlerin çözümünde gerekli özellikleri kendi öğrenme yeteneği ile belirleyerek tatmin edici sonuçlar elde etmesidir. Bu kapsamda 52 adet anten verisi üretilmiștir. Eğitim sürecinde 40 adet ve test aşamasında ise 12 adet veri kullanılmıștır. Test verilerinde elde edilen en düşük Ortalama Karesel Kök Hata (OKKH) performansı, UKSB1 + kaçınma katmanı-1 + UKSB -2 + kaçınma katmanı-2 ile 1.0161 hata değeri olarak belirlenmiștir. Önerilen yöntemle elde edilen sonuçlar High Frequency Simulation Software (HFSS) programinda değerlendirilmiştir. Elde edilen deneysel sonuçlar değerlendirildiğinde derin ögrrenme modelinin üretmiş olduğu sonuçlar ile test verilerinin birbirine çok yakın olduğu gözlemlenmiştir.

Anahtar kelimeler: Mikro şerit anten, Derin öğrenme, Uzun kisa süreli bellek, Optimizasyon, C-Șekilli mikro şerit anten dizisi.

In the microstrip antenna design process, while conductive microstrip patch is placed on the dielectric material, there is a conductive ground plane at the bottom. There are different types of microstrip antenna patch types in the literature. Combinations of $\mathrm{H}, \mathrm{E}, \mathrm{L}$ and $\mathrm{C}$ shapes are used in multi-band antenna designs. Regular structure of microstrip antenna patches are easier to analyze and have a symmetrical pattern of

${ }^{*}$ Corresponding author/Yazışılan Yazar 
radiation. There are many optimizations aimed at the multiband antenna of the designed microstrip antenna [3].

Smith et al. discussed the values $\varepsilon$ and $\mu$ separately and succeeded the design to make both of these two parameter values as negative value [4]. Sivia et al. analyzed and designed circular fractal antenna. It is made Roger RT 5880 Duroid dielectric material that was used as the base of the antenna. In this study, simulation results were compared with those predicted in artificial neural networks [5]. Sarmah et al implemented that ANN applications used on split ring resonator structures are examined, the resonance frequency of the split ring resonators has been optimized by ANN. It is known that resonance frequencies change according to variables such as radius, size and width of antenna structures. Different measured length values were trained in the ANN technique as the data set and optimized process was obtained and the most suitable resonance frequency values were obtained [6]. Deshmukh et al. obtained data from the analysis where substrate of a rectangular microstrip antenna is thicker and in wide frequency cases are compared with the values predicted by training with the artificial neural network. Thus, dimensions of the microstrip antenna have been optimized as desired antenna structure [7]. Deshmukh et al. designed rhombus triangular microstrip antenna design by using ANN technique. In this study, it was tried to estimate all frequency values calculated by changing the thickness of 0.02-0.1 wavelength thickness of air which has thicker dielectric feature of sub layer thicker in 700-6000 $\mathrm{MHz}$ frequency range by training in artificial neural networks [8]. Srivastava et al. estimated parameters on a circular microstrip patch antenna using artificial neural networks. In this study, the size of the radius of the circular patch, which determines the resonance frequency, is an important parameter for mobile communication. Mathematical analyzes were performed with this important parameter and ANN technique was applied to confirm its accuracy [9]. It is seen that this technique was used to evaluate the bandwidth of microstrip antenna designed by Singh et al. Necessary analyzes of the microstrip antenna were performed using a multilayer, feed forward and reverse propagation ANN [10]. Johnson et al. have developed a genetic algorithm based optimization algorithm for broadband microstrip antennas. The main purpose of the study was to obtain $20 \%$ bandwidth at $3 \mathrm{GHz}$ operating frequency. Optimization was performed by removing some square patches in irregular patch geometry [11]. Griffiths et al. aimed to obtain high return loss and bandwidth. They have used genetic algorithm to create elliptical forms on the patch antenna for desired antenna parameters [12].

This study consists of four sections in total. Section I is an introduction and explained previous studies about microstrip antenna design. Section 2 describes antenna structure and its characteristics. Also, it provides details on Deep Learning and Long Short-Term Memory. Section 3 contains results and discussion. The last section is section 4 which includes conclusion.

\section{Material and method}

\section{$2.1 \quad$ C-Shaped antenna array design}

In the proposed C-shaped antenna array, the feed point is provided with a coaxial probe. In order to transfer energy from feed point to entire antenna array, C-shaped patches were intertwined. C-shaped patches include $120^{\circ}$ degree among them. In addition, the annular patch is integrated in the design to properly orient radiation pattern generated by the antenna. The designed microstrip patch was placed on FR4 $\left(\varepsilon_{\mathrm{r}}=4.4\right)$ dielectric material having dimensions of $18.5 \times 18.5 \mathrm{~mm}$. In total, there are 6 parameters to be optimized in the proposed antenna patch geometry. $\mathrm{R}_{1}$ and $\mathrm{R}_{2}$ refer to inner and outer radius of the $\mathrm{C}$-shaped patches. The position of the coaxial probe feed points is shown as $\mathrm{x}$ and $\mathrm{y}$ dimension. Finally, outer and inner radius of the annular ring are determined as $\mathrm{R}_{3}$ and $\mathrm{R}_{4}$ respectively. Proposed antenna design is showed as in Figure 1.

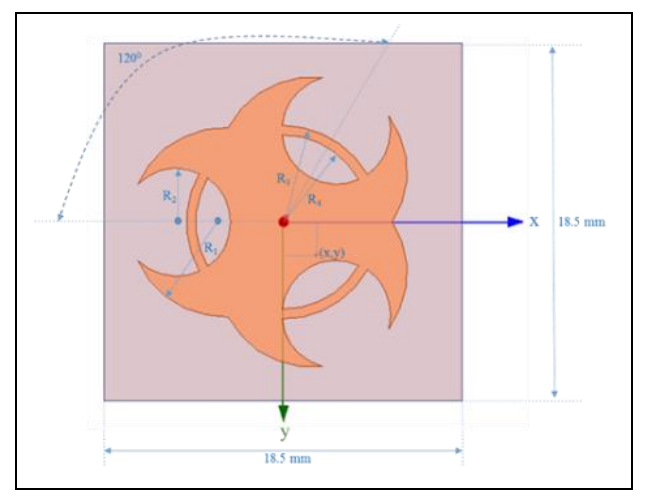

Figure 1. Proposed microstrip antenna design.

The proposed antenna structure has some fixed dimensions. As seen in Table I, height of dielectric substrate is equal to $1.6 \mathrm{~mm}$. Ground plane was located at the bottom of dielectric substrate. It has a square shape with $18.5 \times 18.5 \mathrm{~mm}$. Also, thickness of microstrip patch is $0.01 \mathrm{~mm}$.

Table 1. Dimensions of proposed antenna.

\begin{tabular}{cc}
\hline Parameters & Value \\
\hline Size of Dielectric Substrate & $18.5 \times 18.5 \mathrm{~mm}$ \\
Height of Dielectric & $1.6 \mathrm{~mm}$ \\
Substrate & $18.5 \times 18.5 \mathrm{~mm}$ \\
Size of Ground Plane & $0.01 \mathrm{~mm}$ \\
Height of Microstrip Patch & \\
\hline
\end{tabular}

\subsection{Long short-term memory (LSTM)}

Long-Term Memory, an advanced type of Recurrent Neural Networks (RNNs), was developed in 1997 by Hochreiter and Schmidhuber [13]. In RNN, repeating chain module has an important place. At the same time, LSTM structures include these modules and there is interaction between each other. Figure 2 shows the modules within the LSTM structure.

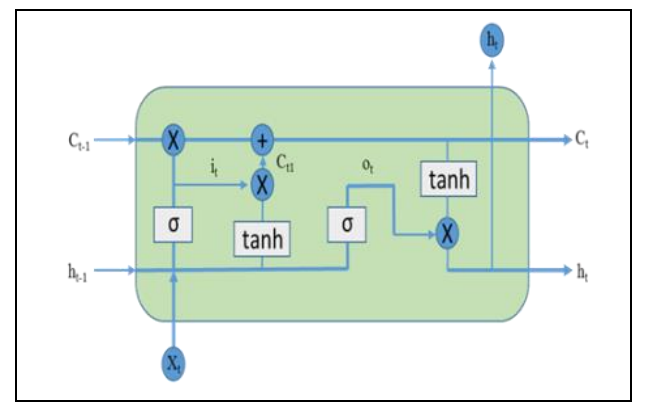

Figure 2. Structure of long short-term memory.

As shown in Figure 2, some information must be eliminated in the first input of the LSTM structure. This is accomplished with sigmoid function and is called as forget gate layer. The inputs for this layer are $\mathrm{h}_{\mathrm{t}-1}$ and $\mathrm{X}_{\mathrm{t}}$. If the output is 0 , information 
should be deleted, whereas an output of 1 indicates that information should be taken into account. The mathematical expression of output function for forget gate layer is given in Eq. 1.

$$
i_{t}=\sigma\left(W_{f} .\left[h_{t-1}, x_{t}\right]+x_{t}\right)
$$

The second layer in the LSTM structure is called input gate. It has two inputs. The first input is proceed with sigmoid function. This input provides information about update process. For the other input, tanh activation function is used. The expression obtained by multiplying these two inputs is summed with $\mathrm{C}_{\mathrm{t}-1}$ and the status of the LSTM structure is updated.

$$
C_{t 1}=\tanh \left(W_{c} \cdot\left[h_{t-1}, x_{t}\right]+b_{c}\right)
$$

When old cell state is updating, it must be transferred to new cell state. It is multiplied by $i_{t}$ to ensure that old cell state information is forgotten. New status values are generated with the formula $\mathrm{i}_{\mathrm{t}} \times \mathrm{C}_{\mathrm{t} 1}$ and status update is performed. The update process is shown in Eq. 3 .

$$
C_{t}=i_{t} \times C_{t-1}+i_{t} \times C_{t 1}
$$

There are two basic processes to update cell status. The sigmoid function is one of these processes. In addition, the tanh activation function interpolates the output values between -1 and 1.

$$
\begin{gathered}
o_{t}=\sigma\left(W_{o} .\left[h_{t-1}, x_{t}\right]+b_{o}\right) \\
h_{t}=o_{t} \times \tanh \left(C_{t}\right)
\end{gathered}
$$

\subsection{Dropout layer}

The dropout layer prevents over fitting in deep learning structure [14]. In the dropout layer, some nodes of the network are removed to prevent the network's dependence on a specific neuron. Thanks to dropout, network can be forced to learn correctly even in the absence of certain information. The standard status of network and its status after the dropout layer are shown in Figure 3.

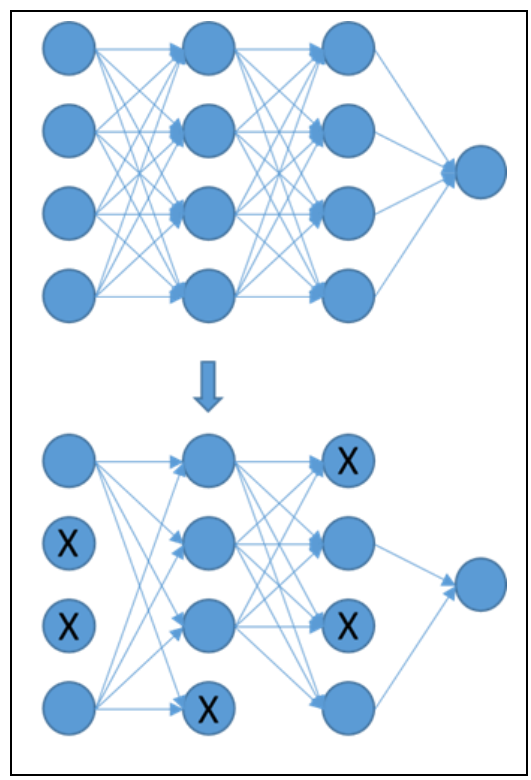

Figure 3. Dropout process.

\subsection{Dataset description}

Generated data set contains S11 data obtained from proposed antenna geometry. 52 pieces of S11 data were generated by HFSS. 40 pieces of them were used to train deep learning structure and 12 pieces of them were used to test the structure. The antenna dimensions have different range to be optimized. The size of $R_{1}$ ranges from 5.4 to $4.7 \mathrm{~mm}$. $R_{2}$ has a radius of 3.2 $2.3 \mathrm{~mm}$. When represented as the feed point ( $\mathrm{x}, \mathrm{y})$, they can have different values between 2.7-0.5 mm. The outer and inner radius of ring shaped patch element range from 5.3 to $4 \mathrm{~mm}$.

\subsection{Proposed method}

In the proposed method, different LSTM connection types are used to optimize dimensions of C-shaped microstrip antennas. It is also used to prevent over-fitting and to select important features [15]. Five different structures were used in the proposed method. These structures can be classified based on existence of dropout layer. In addition, different cell numbers were used in each LSTM layer. These cell numbers are 50, 100, 150 and 200 respectively. Also, each dropout layer has 0.5 probability value. LSTM-1, LSTM-1 + dropout-1, LSTM-1 + LSTM-2, LSTM-1 + dropout-1 + LSTM-2 and LSTM-1 + dropout$1+$ LSTM-2 + dropout- 2 were used as trained model. In the proposed method, S11 data obtained according to various antenna sizes were used to train the structure of deep learning.

The main advantage of proposed method is that it can learn better than other machine learning methods and can predict different data correctly. Deep learning structures in optimization on antenna dimensions have achieved remarkable results. In this article, deep learning model results are given. Figure 4 shows the block diagram of the proposed method.

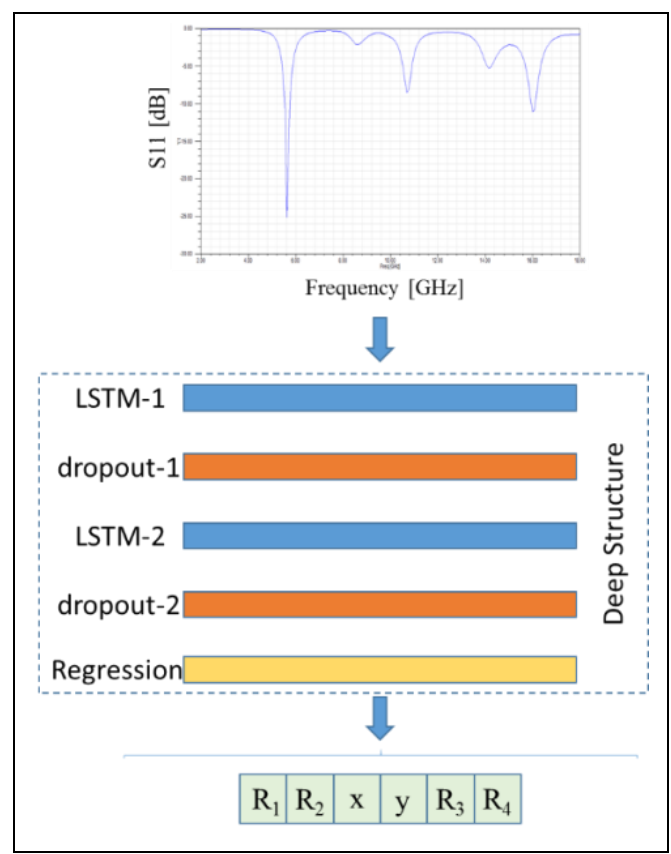

Figure 4. Algorithm of the proposed method.

\section{Results and discussion}

Five different deep learning models were used to optimize the proposed microstrip antenna dimensions. There are a number of parameters in training of deep learning models. Adaptive Moment Estimation (Adam) was used as optimization algorithm. The maximum number of epochs is 1500. An 
adaptive learning rate was used by reducing the learning rate by $80 \%$ in every 125 epochs. The test was performed in every 500 epochs. Comparative training and test graphs are presented in Figure 5.

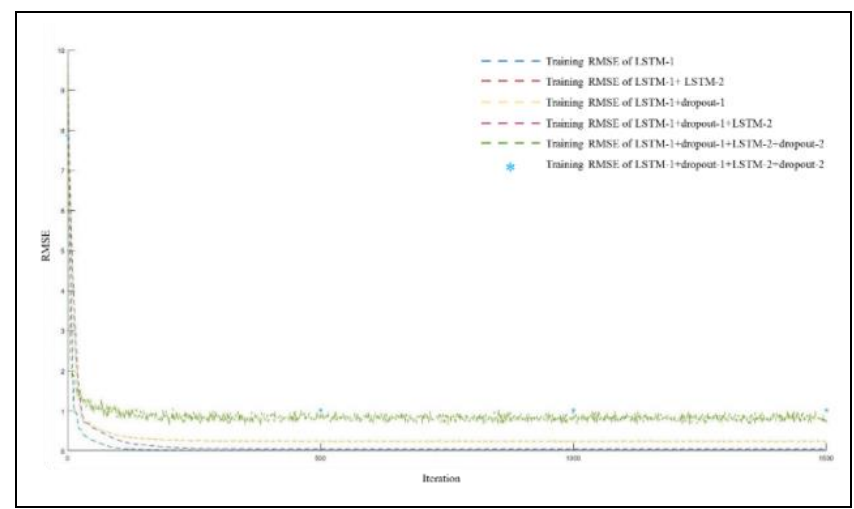

Figure 5. Training and testing process for each deep structure.

The lowest RMSE result was obtained with LSTM-1 + dropout1 + LSTM-2 + dropout-2 model with 50 cells. In LSTM-1 model, the lowest RMSE value was obtained as 1.0484. In the LSTM-1 + dropout- 1 model, the RMSE value was reduced by 1,038 . In the LSTM-1 + LSTM-2 model, the RMSE value of 1.0467 was reached. The RMSE value of the LSTM-1 + dropout-1 + LSTM-2 model was further reduced and a 1.038 RMSE value was obtained. Comparative test RMSE values are given in Figure 6.

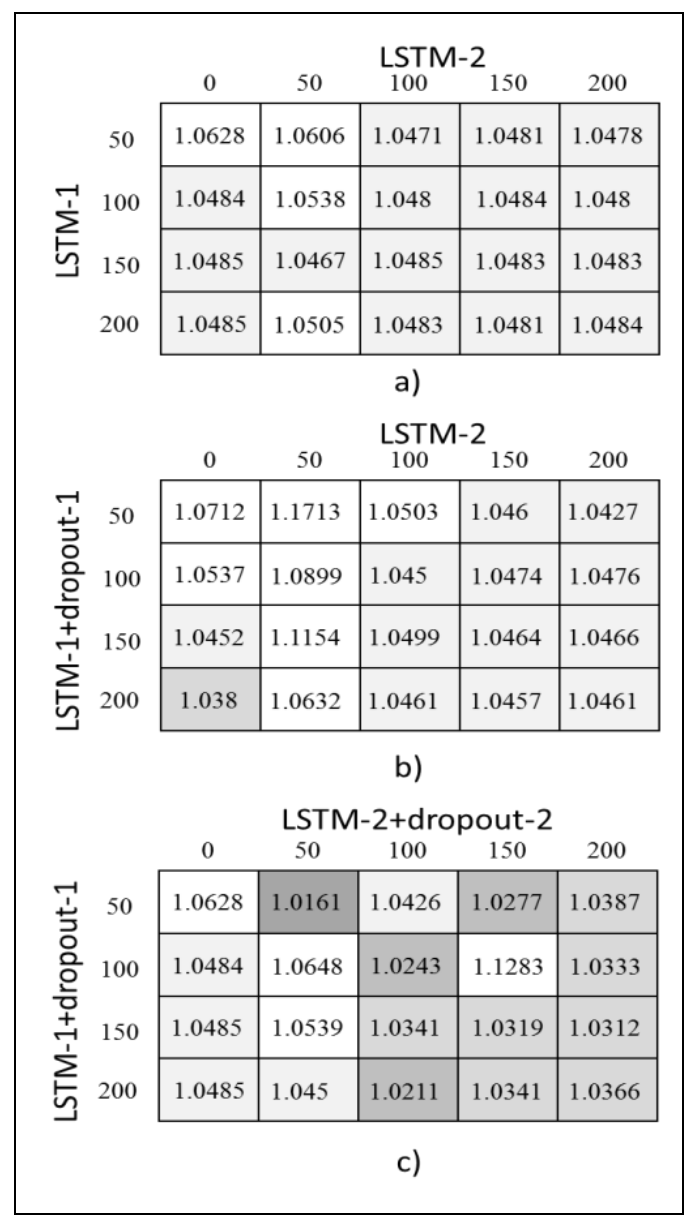

Figure 6. RMSE values for. (a): Deep structure with no dropout layer. (b): Deep structure with dropout-1 layer. (c): Deep structure with dropout-1 and dropout-2 layer.
It can be seen that RMSE value decreases as number of dropout layers increases as in Figure 6. There is no distinct relation between RMSE value and number of cell. As seen in Figure 6, the lowest RMSE value was reached with LSTM-1 + dropout-1 + LSTM-2 + dropout- 2 model with 50 hidden cells. Some test results obtained with this model in mm level are shown in Table 2.

Table 2. Some test dimension about real/LSTM model.

\begin{tabular}{cccccc}
\hline Parameters & Test 1 & Test 2 & Test 3 & Test 4 & Test 5 \\
\hline $\mathrm{R}_{1}$ & $4.8 / 5.0$ & $5 / 5.1$ & $4.7 / 4.9$ & $4.9 / 5$ & $5.3 / 5.2$ \\
$\mathrm{R}_{2}$ & $2.4 / 2.6$ & $2.6 / 2.5$ & $2.4 / 2.7$ & $2.8 / 2.8$ & $3 / 3$ \\
$\mathrm{x}$ & $2.1 / 2$ & $2 / 1.9$ & $1.8 / 1.8$ & $2 / 1.9$ & $1.7 / 1.7$ \\
$\mathrm{y}$ & $2.1 / 2$ & $2 / 1.9$ & $1.8 / 1.8$ & $2 / 1.9$ & $1.7 / 1.6$ \\
$\mathrm{R}_{3}$ & $5.3 / 5.2$ & $5.3 / 5.1$ & $5.3 / 5.2$ & $5.3 / 5.2$ & $4.7 / 5.0$ \\
$\mathrm{R}_{4}$ & $4.8 / 4.8$ & $4.8 / 4.8$ & $4.8 / 4.7$ & $4.5 / 4.6$ & $4.3 / 4.5$ \\
\hline
\end{tabular}

The analysis of antennas was performed according to Real / LSTM model results as in Table 2. Figure 7 shows the analysis of Test 1 , Test 2 and Test 3 antenna designs.

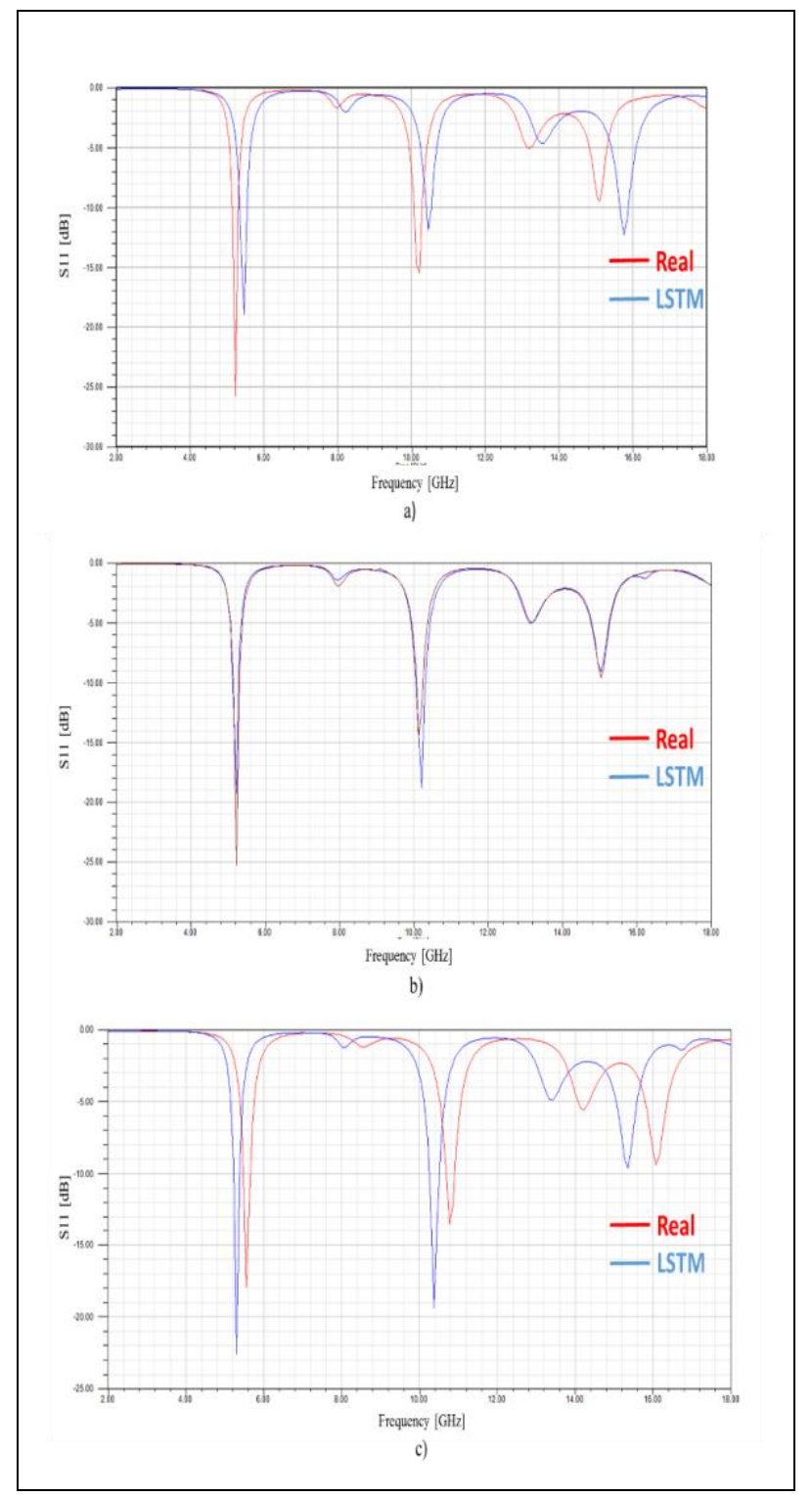

Figure 7. Real/LSTM Model Results. (a): Test 1. (b): Test 2. (c): Test 3. 
In Figure 7, Real and LSTM results were well-converged with each other for Test 2 . However, these results in Test 1 and Test 3 were not so pretty as in Test 2 . Since, changes in antenna dimension has more affects to antenna characteristic at high frequency. When operating frequency increases, it makes dimension smaller as in Figure 7. Thus, sensitivity of converges in proposed method should be in $\mu \mathrm{m}$.

\section{Conclusion}

In this study, dimension optimization of antenna design for multi band applications has been realized by using $C$ shaped antenna geometries with higher capability unlike rectangular, circle and triangle shaped. In the C-shaped antenna design, it is aimed to improve some basic dimensions by using deep learning models in order to obtain shorter optimization performance. As a result of these models, antenna designs were re-evaluated in HFSS 13.0 high frequency simulation program and LSTM-1 + Dropout layer-1 + LSTM-2 + Dropout layer-2 was found to be the most progressive deep learning model. It has been found that conventional methods are insufficient to improve antenna properties which do not show a linear distribution. In this article, this problem has been solved by using deep learning model. In particular, although changes in the $\mu \mathrm{m}$ level of the antenna dimensions designed at high frequencies had a significant effect on the antenna properties, deep learning model performance is very close to the desired antenna designs. Thanks to this study, it is understood that deep learning models can be reduced optimization time in antenna design.

\section{Author contribution statements}

In the scope of this study, Umut Özkaya contributed to the desing and obtainig the results; Levent Seyfi contibuted to the design and literature review and Șaban Öztürk contibuted to the design and literature review.

\section{Ethics committee approval and conflict of interest statement}

There is no need to obtain permission from the ethics committee for the article prepared.

There is no conflict of interest with any person / institution in the article prepared.

\section{References}

[1] Saunders SR. Antennas and Propagation for Wireless Communication Systems. $5^{\text {th }}$ ed. New York, USA, Wiley, 2003.

[2] Bahl IJ, Bhartia P. Microstrip Antennas. $4^{\text {th }}$ ed. Dedham, Mass, USA, Artech House, 1980.
[3] Modiri A, Kiasaleh K. "Efficient design of microstrip antennas for SDR applications using modified PSO algorithm". IEEE Transactions on Magnetics, 47(5), 1278-1281, 2011.

[4] Smith DR, Padilla WJ, Vier DC, Nemat-Nasser SC, Schultz S. "Composite medium with simultaneously negative permeability and permittivity". Physical Review Letters, 84(18), 4184-4187, 2000.

[5] Sivia JS, Pharwaha APS, Kamal TS. "Analysis and design of circular fractal antenna using artificial neural networks". Progress in Electromagnetics Research, 56, 251-267, 2013.

[6] Sarmah K, Sarma KK, Baruah S. "ANN based optimization of resonating frequency of split ring resonator". IEEE Symposium on Computational Intelligence for Communication Systems and Networks (CIComms), Orlando, USA, 9-12 December 2014.

[7] Deshmukh AA, Kulkarni SD, Venkata APC, Phatak NV. "Artificial neural network model for suspended rectangular microstrip antennas". Procedia Computer Science, 49, 332-339, 2015.

[8] Deshmukh AA, Venkata APC, Nagarbowdi S, Kulkarni SD. "Artificial neural network model for suspended equilateral triangular microstrip antennas". International Conference on Communication, Information \& Computing Technology (ICCICT), Mumbai, India, 1-4 January 2015.

[9] Srivastava M, Saini S, Thakur A. "Analysis and parameter estimation of microstrip circular patch antennas using artificial neural networks". International Conference on Soft Computing: Theories and Applications, Singapore, 17-18 July 2016.

[10] Singh P, Singh VK, Lala A, Bhoi AK. "Design and analysis of microstrip antenna using multilayer feed-forward backpropagation neural network (MLPFFBP-ANN)". International Conference in Communication, Devices and Networking, Sikkim, India, 3-4 June 2017.

[11] Michael J, Rahmat-Samii Y. "Genetic algorithms and method of moments (GA/MOM) for the design of integrated antennas". IEEE Transactions on Antennas and Propagation, 47(10), 1606-1614, 1999.

[12] Griffiths LA, Furse C, Chung YC. "Broadband and multiband antenna design using the genetic algorithm to create amorphous shapes using ellipses". IEEE Transactions on Antennas and Propagation, 54(10), 2776-2782, 2006.

[13] Hochreiter S, Schmidhuber J. "Long short-term memory". Neural Computation, 9(8), 1735-1780, 1997.

[14] Schmidhuber, J. "Deep learning in neural networks: An overview". Neural networks, 61, 85-117, 2015.

[15] Wan H, Guo S, Yin K, Liang X, Lin Y. “CTS-LSTM: LSTM-based neural networks for correlated time series prediction". Knowledge-Based Systems, 191, 1-10, 105239, 2020. 